\title{
Association between Paternal Education and CariesPrevalence in Children: A Cross Section Study in Udaipur -Rajasthan
}

\author{
Dr. Abhinandan Anand Katageri ${ }^{1}$, Dr. Ruchi Arora ${ }^{2}$, Dr. Deepak P. Bhayya ${ }^{3}$ \\ ${ }^{I}$ (Department of Pedodontics and Preventive Dentistry / RUHS. INDIA) \\ ${ }^{2}$ (Department of Pedodontics and Preventive Dentistry / RUHS. INDIA) \\ ${ }^{3}$ (Department of Pedodontics and Preventive Dentistry / PAHER. INDIA)
}

\begin{abstract}
It is widely acknowledged that the behaviour of parents affects their children's health.The objective of this study was to determine the role of paternal education on oral health status in their children. A total of 465 children aged between 8-14 years studying in Government schools of Udaipur city were considered for this study. Clinical data was obtained through DMF-T based on WHO criteria and interview was conducted to know the paternal education level. Data was subjected for statistical analysis and it was observed that child with illiterate father had a higher chance of caries than that of literate father.
\end{abstract}

Keywords: Caries, DMF-T, Decayed,Literate, Paternal education,Socio-economic status

\section{Introduction}

Dental caries is a chronic disease that causes discomfort and affects quality of life. It deserves special attention because of its high prevalence and severity, especially among specific population groups.Despite the significant reduction of epidemiological indicators, dental caries is still highly prevalent among children in disadvantaged socioeconomic conditions [1].Among the various possibilities of using socioeconomic indicators, parental education has been used as one of the best predictors of their children's health, especially in developing countries $[2,3]$. Low parental education, especially of fathers, is a risk factor for dental caries in children $[4,5,6]$

\section{Aims And Objectives}

The objective of this study was to find out the prevalence and severity of dental caries among schoolchildren in Udaipur and to examine its possible association with paternal education.

\section{Materials And Methods}

A cross sectional study involving 10-14years School going children was carried out at various Government schools of rural and urban Udaipur.Sample size of 465 was considered. Clinical information on caries was obtained through DMF-T and dmf-t according to World Health Organization criteria 1997 [7].Intraoral examination performed by single observer was carried out using mouth mirrors and explorers which were previously packed and sterilized by autoclaving.For non-clinical data, interviews were conducted with each child asking about parent's education and oral hygiene habits. The data was entered into the SPSS 17.0 software and were analysed in a descriptive way.Association tests were performed using Chi-squared or Fisher's exact test.Odds Ratios (OR) and confidence intervals were also calculated and converted into Prevalence Ratios (PR).

\section{Results}

A total of 465 children were examined, out of which 204 were girls with 162 of them having caries and 261 were boys and 122 of them had positive finding of caries[Table 1]. It was observed 191 fathers were illiterate of which $75.9 \%$ children had caries and 77 were graduates of which $42.9 \%$ had caries [Table 2]. The prevalence of dental caries in children was highest for school attended fathers $41.1 \%$ and lowest for children of graduate fathers $16.6 \%$ and the difference was found significant [Table 3].

TABLE 1: Distribution of the study subjects based on gender

\begin{tabular}{|c|c|c|c|c|c|c|}
\hline & \multirow{2}{*}{\multicolumn{2}{|c|}{ Children }} & \multicolumn{2}{|c|}{ Prevalence of Caries } & \multirow[b]{2}{*}{ Total } & \multirow[t]{2}{*}{$\mathrm{P} \uparrow$} \\
\hline & & & Yes & No & & \\
\hline \multirow[t]{2}{*}{ Sex } & MALE & $\begin{array}{l}\text { Count } \\
\text { \% within Sex } \\
\text { \% within caries }\end{array}$ & $\begin{array}{c}162 \\
62.1 \% \\
57.0 \%\end{array}$ & $\begin{array}{c}99 \\
37.9 \% \\
54.7 \%\end{array}$ & $\begin{array}{c}261 \\
100.0 \% \\
56.1 \%\end{array}$ & \multirow[t]{2}{*}{0.63} \\
\hline & FEMALE & $\begin{array}{l}\text { Count } \\
\% \text { within Sex } \\
\% \text { within caries }\end{array}$ & $\begin{array}{c}122 \\
59.8 \% \\
43.0 \%\end{array}$ & $\begin{array}{c}82 \\
40.2 \% \\
45.3 \%\end{array}$ & $\begin{array}{c}204 \\
100.0 \% \\
43.9 \%\end{array}$ & \\
\hline
\end{tabular}


TABLE 2: Distribution of caries based on paternal education

\begin{tabular}{|c|c|c|c|}
\hline & & \multicolumn{2}{|c|}{ Caries } \\
\hline & & Yes & No \\
\hline \multirow{3}{*}{ Illiterate } & Count & 145 & 46 \\
\hline & $\%$ within Fathers Education & $75.9 \%$ & $24.1 \%$ \\
\hline & $\%$ within decayed & $51.1 \%$ & $25.4 \%$ \\
\hline \multirow{3}{*}{ Schooling } & Count & 106 & 91 \\
\hline & $\%$ within Fathers Education & $53.8 \%$ & $46.2 \%$ \\
\hline & $\%$ within decayed & $37.3 \%$ & $50.3 \%$ \\
\hline \multirow{3}{*}{ Graduation and above } & Count & 33 & 44 \\
\hline & $\%$ within Fathers Education & $42.9 \%$ & $57.1 \%$ \\
\hline & $\%$ within decayed & $11.6 \%$ & $24.3 \%$ \\
\hline
\end{tabular}

TABLE 3: Paternal education and prevalence of caries

\begin{tabular}{|c|l|c|c|}
\hline \multirow{2}{*}{ Illiterate } & Count & Total & P† \\
& Fathers Education (\%) & 191 & $100.0 \%$ \\
& Children with caries (\%) & $41.1 \%$ & \\
\hline \multirow{2}{*}{ Schooling } & Count & 197 & \\
& Fathers Education (\%) & $100.0 \%$ & 0.000 \\
& Children with caries (\%) & $42.4 \%$ & \\
Graduation and above & Count & $100.0 \%$ & \\
& Fathers Education (\%) & $16.6 \%$ & \\
\hline
\end{tabular}

$\dagger$ Pearson's chi-square test

TABLE 4: Logistic Regression

\begin{tabular}{|l|c|c|}
\hline \multicolumn{1}{|c|}{ Variables } & $\begin{array}{c}\text { Odds ratio } \\
(95 \% \text { Confidence Interval })\end{array}$ & $\mathrm{p}$ - value \\
\hline Gender & 1.144 & 0.53 \\
& $(0.747-1.752)$ & 0.03 \\
\hline Fathers Education & 1.648 & \\
\hline
\end{tabular}

\section{Discussion}

The high response rate obtained in the study, the examiner's calibration process and the proper degree of diagnostic reproducibility obtained during the data collection suggested a good internal validity of the study. The prevalence of dental caries was $61.1 \%$ which was higher than the study done by Dhar V. et al 2007.In the present study the ' $\mathrm{D}$ ' (decayed) component was the largest contributor to the DMF-T score.This reflects the limited access of children to dental services in the rural area. In fact, if the private service is not financially accessible for rural families, the public service is also unable to meet the needs.Lower paternal schooling was shown to be associated with the prevalence of dental caries. Result was similar in the study done by Traebert J.2011.The results of this study pointed to the needof understanding the oral health-disease processas an expression of style and living conditions,these being capable of explaining the epidemiological profile of the population.In fact, this study supports the assertion of the existence of a directly proportional relationship between education levels and dental caries.Higher levels of education can mean better working conditions, higher family income and, therefore, better access to goods and services.In fact, the association between low paternal schooling and higher rates of dental caries evidences the importance of social and economic factors in the health-disease process.

\section{Conclusion}

To improve the oral health status of the studied population of schoolchildren, it must be recognized that low paternal education might represent low economic level, and consequently that these fathers do not have access to information about the essential care to provide and maintain their children's oral health.It can be concluded that the prevalence of dental caries was found to be statistically higher among the male children of fathers who had a lower level of education.

\section{References}

[1]. Vargas CM, Ronzio CR. Disparities in early childhood caries. MC Oral Health. 2006; 6:1-5.

[2]. Petersen PO. The World Oral Health Report 2003: continuous improvement of oral health in the 21th century - the approach of the WHO Global Oral Health Programme. Community Dent Oral Epidemiol. 2003; 31:3-24

[3]. AaVictora CG, Huttly SRA, Barros FC, Lombardi C, Vaughan JP. Maternal education in relation to early and late child health outcomes: findings from a Brazilian cohort study. Soc Sci Med 1992;34:899-905 
[4]. Saito SK, Deccico HMU, Santos MN. Efeito da pratica de alimentacaoinfantil e de fatoresassociadossobre a ocorrencia de carie dental em pre-escolares de 18 a 48 meses. Rev Odontol Univ Sao Paulo. 1999;13:5-11

[5]. Peres KGA, Bastos JRM, Latorre MRDO. Severidade de carieemcriancas e relacao com aspectossociais e comportamentais. Rev SaudePublica. 2000; 34:402-8.

[6]. Traebert J, Guimaraes LA, Durante EZT, Serratine ACP. Low maternal schooling and severity of dental caries in Brazilian pre-school children. Oral Health Prev Dent. 2009; 7:39-45.

[7]. World Health Organization. Oral health survey: basic methods, ed 4. Geneva: World Health Organization, 1997

[8]. Dhar V, Jain A, Van Dyke TE, Kohli A. Prevalence of dental caries and treatment needs in the school-going children of rural areas in Udaipur district. J Indian Soc Pedod Prevent Dent. 2007 Sep; 119-121

[9]. Traebert J, Jinbo Y de, Lacerda JT. Association between maternal schooling and caries prevalence: A cross-sectional study in southern Brazil. 